\title{
Peran Perbankan Syariah terhadap Pertumbuhan Ekonomi Indonesia
}

\author{
Safaah Restuning Hayati \\ Forum Studi Ekonomi "Equilibrium"
}

\begin{abstract}
Abstrak
Paper ini bertujuan untuk menganalisis peran perbankan syariah bagi pertumbuhan ekonomi. Pesatnya perkembangan perbankan syariah di Indonesia yang harus diimbangi dengan kontribusi terhadap pertumbuhan ekonomi menjadi latar belakang penulisan paper ini. Analisis dalam paper ini menggunakan metode Ordinary Least Square (OLS) untuk mengetahui berapa besar pengaruh perbankan syariah bagi pertumbuhan ekonomi yang direpresentasikan dengan Product Domestic Bruto. Hasil uji model regresi menemukan bahwa total aset perbankan syariah tidak berpengaruh signifikan terhadap PDB, sedangkan total pembiayaan perbankan syariah berpengaruh signifikan (positif) terhadap PDB. Variabel total aset dan total pembiayaan bank syariah mampu menjelaskan pengaruhnya sebesar 33,8\% terhadap variabel PDB. Hal ini berarti bahwa perbankan syariah memiliki peran sangat kecil terhadap pertumbuhan ekonomi di Indonesia. Solusi yang diberikan adalah perbankan syariah harus meningkatkan market share, meningkatkan porsi pembiayaan dengan skim muḍarabah, memperkuat regulasi, meningkatkan kualitas dan kuantitas sumber daya insani serta mengadaptasi kemajuan teknologi.
\end{abstract}

\begin{abstract}
The paper analyzes the role of Islamic banking for economic growth in Indonesia. The rapid development of Islamic banking in the country followed the economic growth was the research basis of the paper. The analysis in this paper uses Ordinary Least Square method to determine how much Islamic banking influenced the growth represented by Gross Domestic Product (GDP). The result of regression model testing found that the total assets of Islamic banking had no significant effect (negative) on GDP, while the Islamic banking financing process had significant process had significant effect (positive) on GDP. Variable total assets and total financing of Islamic banking are able to explain the effect $33.8 \%$ of GDP variable. This means that Islamic banking has a very small role related to economic growth in Indonesia. The research indicates that the solution for increasing for the influence of Islamic banking could include increasing market share and increasing the share of muḍarabah financing schemes, strengthening
\end{abstract}


regulation, improving the quality and quantity of human resources, and adapting technological advances.

Keywords: Islamic banking, economic growth, Ordinary Least Square.

\section{Pendahuluan}

Bank Syariah di Indonesia, baik yang berbentuk Bank Umum Syariah (BUS) atau Unit Usaha Syariah (UUS) maupun Bank Pembiayaan Rakyat Syariah (BPRS) berada di bawah naungan Undang-Undang No. 21 tahun 2008 tentang Perbankan Syariah. Peraturan lain terkait dengan Lembaga Keuangan Syariah (LKS) serta pendukung pertumbuhan ekonomi syariah di Indonesia adalah UU No. 19 tahun 2008 tentang Surat Berharga Syariah Negara (SBSN), UU No. 3 tahun 2006 tentang Peradilan Agama untuk Ekonomi Syariah, UU No. 41 tahun 2004 tentang Wakaf, UU No. 38 tahun 1999 tentang Pengelolaan Zakat, dan lain sebagainya. ${ }^{1}$

Dukungan dari aspek hukum dan perundang-undangan menjadikan pertumbuhan lembaga keuangan syariah (LKS) dan sektor keuangan syariah semakin pesat karena telah memiliki landasan dan kepastian hukum yang jelas. Pada 1992 lahir Bank Syariah pertama. Tahun 1994 muncul asuransi syariah (takaful). Tahun 1999 muncul Unit Usaha Syariah (UUS) yang diawali oleh UUS Bank IFI. Kemudian tahun 2000 berdiri Pasar Uang antar Bank Syariah (PUAS) dan muncul Jakarta Islamic Index (JII). ${ }^{2}$

Dibandingkan dengan negara-negara muslim lain, pertumbuhan perbankan syariah di Indonesia menunjukkan angka stabil dan meningkat hingga mencapai 49,2\% pada 2011. Selain itu, grafik tersebut menunjukkan bahwa dalam dua tahun terakhir (2010-2011) Indonesia menjadi negara dengan pertumbuhan perbankan syariah tertinggi meskipun pada 2012 menurun menjadi 34,1\%. Perbandingan pertumbuhan perbankan syariah di Indonesia dengan negara-negara Muslim lainnya dapat dilihat pada grafik berikut: ${ }^{3}$

\footnotetext{
${ }^{1}$ Tim Penyusun, Kompilasi Perundang-Undangan tentang Ekonomi Syariah (Jakarta: Gaung Persada Press, 2008).

${ }^{2}$ Ascarya, Akad dan Produk Bank Syariah (Jakarta: Raja Grafindo Persada, 2007), 207208.

${ }^{3}$ Ascarya, "Peran Riset untuk Mendukung Kebijakan Pemerintah dalam Pengembangan Ekonomi Islam dan Bisnis Syariah". Paper dipresentasikan dalam Seminar Nasional IAEI (Bogor: STEI Tazkia, 2013), 6-7.
} 
Gambar 1. Perbandingan Perkembangan Perbankan Syariah

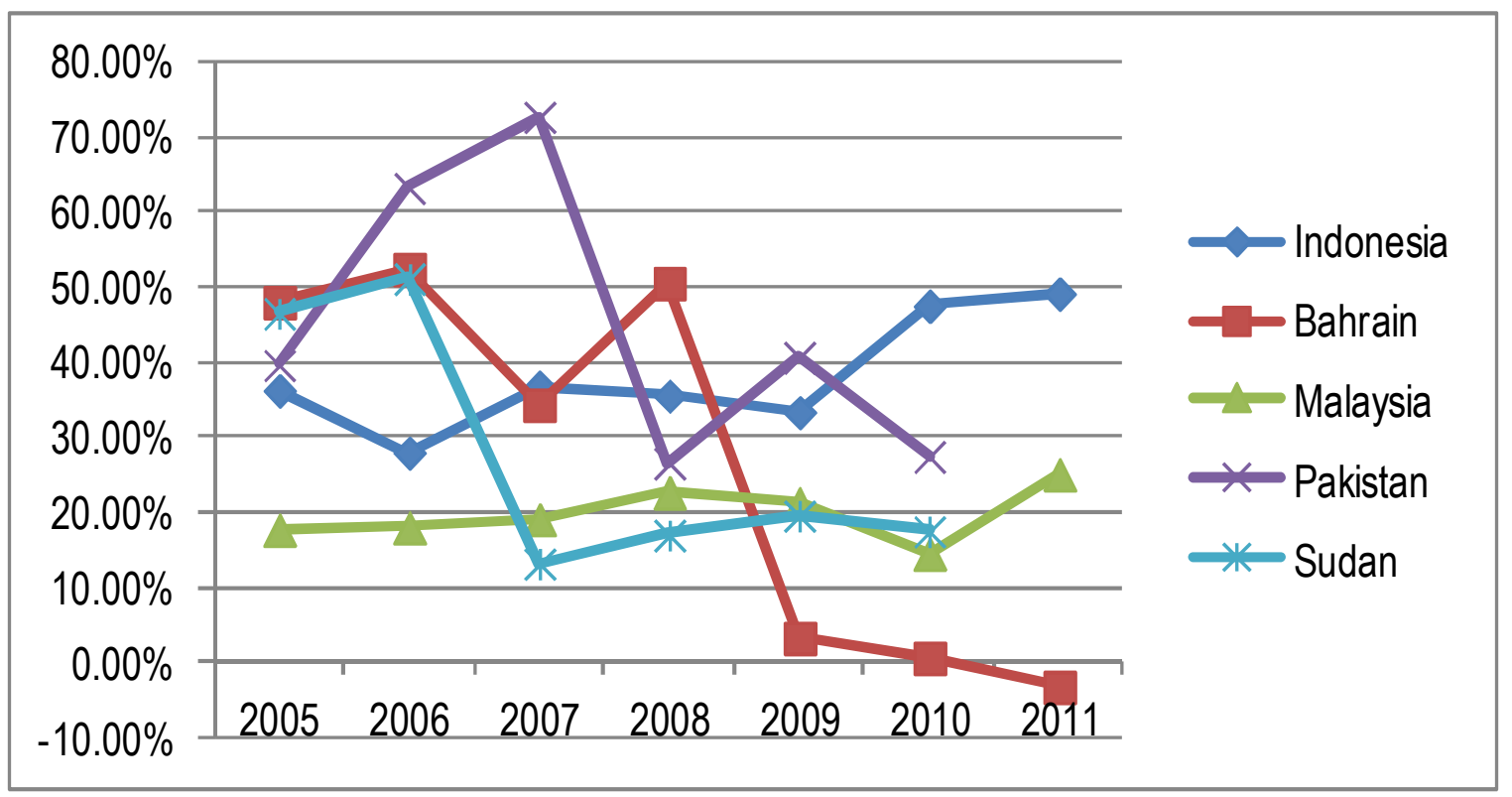

Sejak kebangkitan ekonomi syariah di Indonesia tahun 1990-an yang ditandai dengan berdirinya Bank Muamalat Indonesia, kajian-kajian mengenai model ekonomi syariah semakin menjamur. Kehadiran bank pertama yang berbasis syariah ini diikuti dengan kehadiran lembaga-lembaga keuangan syariah lainnya. Perbankan syariah hadir dengan kinerja yang tetap baik saat perbankan konvensional dilanda krisis kepercayaan dan krisis likuiditas. Ditambah lagi dengan krisis ekonomi sejak tahun 1997-1998, kepercayaan terhadap bank konvensional dan sistem kapitalisme semakin melemah. ${ }^{4}$

Muhammad Abduh dan Mohd Azmi Omar menemukan bukti bahwa dalam waktu jangka panjang, pengembangan keuangan Islam memiliki peran positif dan penting serta berhubung dengan pertumbuhan ekonomi dan pertambahan modal. Pembiayaan dalam negeri yang diberikan sektor perbankan syariah telah berkontribusi pada pertumbuhan ekonomi Indonesia. Dengan kata lain, perbankan Islam telah terbukti efektif sebagai perantara keuangan yang memfasilitasi peralihan dana dari "rumah tangga surplus 2007), 61 .

${ }^{4}$ Ridjaluddin Fadjar Noegraha, Nuansa-Nuansa Ekonomi Islam (Jakarta: Sejahtera, 
untuk rumah tangga defisit". Hubungan antara pembiayaan syariah dan pertumbuhan ekonomi di Indonesia berperan untuk merangsang pertumbuhan ekonomi dan mendorong perkembangan perbankan syariah di Indonesia. ${ }^{5}$

Muhammad Abduh dan Nazreen T. Chowdhury melakukan penelitian mengenai peran perbankan syariah dalam pertumbuhan ekonomi di Bangladesh dengan menggunakan metodologi kointegrasi. Berdasarkan penelitian tersebut, pembiayaan bank syariah dalam waktu jangka panjang dan jangka pendek memiliki hubungan positif dengan pertumbuhan ekonomi. Dengan kata lain, perkembangan perbankan syariah juga akan mendukung tujuan negara dalam meningkatkan pendapatan mereka. Oleh karena itu, pengembangan perbankan syariah menjadi salah satu kebijakan yang dipertimbangkan oleh pemerintah Bangladesh. ${ }^{6}$

Penelitian lain terkait pembangunan ekonomi, Nedal El-Ghattis dalam penelitiannya menyimpulkan bahwa konsep bagi hasil dalam Islam mendorong pembangunan ekonomi melalui pembagian pendapatan yang sama dan menghasilkan manfaat lebih besar untuk keadilan sosial dan pertumbuhan jangka panjang. Skema pembagian laba-rugi meningkatkan efisiensi alokasi modal dan meningkatkan produktivitas. Selanjutnya, alokasi dana didasarkan pada keberhasilan proyek. Sedangkan skema bagi hasil mendorong investor mendepositokan uang mereka dan mereka akan menerima bagian dari keuntungan bank. Sistem keuangan Islam terbukti lebih stabil daripada sistem perbankan konvensional karena penghapusan pembiayaan utang. Hal ini juga mengurangi inflasi ekonomi sebab dalam keuangan Islam bahwa pasokan uang tidak diperbolehkan beredar melebihi pasokan barang. ${ }^{7}$

Penelitian terkait juga dilakukan Khaled Abdalla. Ia menyimpulkan bahwa ada hubungan yang signifikan secara statistik antara bank syariah dengan pembangunan ekonomi. Meskipun pencapaian aset dan deposito bank syariah cukup tinggi dalam ukuran aset dan deposito, sumbangsih bank syariah di Yordania terhadap pembangunan ekonomi masih marginal jika dibandingkan dengan sumbangsih dari sistem perbankan konvensional.

\footnotetext{
${ }^{5}$ Muhammad Abduh dan Mohd Azmi Omar, "Islamic Banking And Economic Growth: The Indonesian Experience," International Journal of Islamic and Middle Eastern Finance and Management 5, No. 1 (2012): 35-47.

${ }^{6}$ Nazreen T. Chowdhury dan Muhammad Abduh, "Does Islamic Banking Matter for Economic Growth in Bangladesh?," Journal of Islamic Economics, Banking and Finance 8, No. 3 (2012): 104-113.

${ }^{7}$ Nedal El-Ghattis, "Islamic Banking's Role in Economic Development: Future Outlook", diunduh dari http://www.cba.edu.kw/wtou/ download/conf4/nedal.pdf tanggal 14 Juli 2013.
} 
Dalam hal ini, bank-bank Islam memiliki peran penting dalam perekonomian negara untuk menjadi organ yang efektif, bekerja lebih efisien, dan dapat bersaing dengan lembaga keuangan konvensional. Bank Islam diharapkan mampu berkontribusi dalam memajukan pembangunan ekonomi selain mencapai tingkat sosial pembangunan kerjasama, solidaritas, dan persaudaraan antara anggota masyarakat, deposan, dan investor. ${ }^{8}$

Kehadiran lembaga keuangan syariah dan lembaga sosial berbasis syariah seharusnya semakin mewujudkan kemaslahatan dan keadilan sosial sebagaimana yang menjadi tujuan ekonomi syariah. Mungkinkah perbankan syariah menjadi jawaban dari persoalan-persoalan pembangunan di Indonesia? Berapa besar peran perbankan syariah bagi pertumbuhan ekonomi di Indonesia? Hal ini perlu dikaji lebih lanjut.

Penelitian ini menggunakan metode Ordinary Least Square (OLS) untuk mengukur parameter. Penggunaan metode OLS digunakan untuk mencari suatu garis lurus yang melewati sekumpulan titik observasi. Kriteria yang digunakan adalah meminimalkan jumlah kuadrat residual. ${ }^{9}$ Jika model regresi linier berganda yang diukur melalui OLS memenuhi asumsi GaussMarkov (data berdistribusi normal dan bebas dari heterikedastisitas), maka dapat ditunjukkan bahwa parameter yang diperoleh bersifat BLUE (Best Linear Unbiased Estimator). Best yang dimaksud dalam teorema ini adalah parameter yang dihasilkan memiliki varian terkecil dibandingkan dengan parameter yang diperoleh melalui metode non-OLS. ${ }^{10}$ Berdasarkan perkiran model, spesifikasi persamaan model yang diperoleh adalah:

$\begin{array}{ll} & \mathrm{PDB}=\beta_{0}+\beta_{1} \mathrm{AST}+\beta_{2} \mathrm{FINC}+\varepsilon \\ \text { PDB } & : \text { Produk Domestik Bruto } \\ \text { AST } & : \text { Total Aset (assets) } \\ \text { FINC } & : \text { Total Pembiayaan (financing) } \\ \beta_{0} & : \text { Konstanta } \\ \beta_{1} & : \text { Koefisien variabel AST } \\ \beta_{2} & : \text { Koefisien variabel FINC } \\ \varepsilon & : \text { Error term }\end{array}$

${ }^{8}$ Khaled Abdalla Mohd Al-Tamimi, "The Role of Islamic Banks Operating in Jordan in Economic Development," Journal of Economics and Sustainable Development 4, No. 8 (2013): 46-59.

${ }^{9}$ Moch. Doddy Ariefianto, Ekonometrika Esensi dan Aplikasi dengan Menggunakan Eviews (Jakarta: Erlangga, 2012), 12.

${ }^{10}$ Ariefianto, Ekonometrika Esensi, 19. 


\section{Diskursus Perbankan Syariah di Indonesia}

Peluang pendirian bank syariah di Indonesia semakin terbuka lebar setelah adanya rekomendasi dari lokakarya ulama tentang bunga bank di Bogor pada bulan Agustus 1990. Selanjutnya diselenggarakan Musyawarah Nasional (Munas) IV Majelis Ulama Indonesia dan dibentuk kelompok kerja untuk mendirikan bank syariah. Hasil kerja tim melahirkan Bank Muamalat Indonesia (BMI) dengan modal awal sebesar Rp 106.126.382.000,00 dan beroperasi pada tanggal 1 Mei 1992. ${ }^{11}$ Setelah kelahiran Bank Muamalat Indonesia, muncul banyak bank syariah di Indonesia, baik dalam bentuk Bank Umum Syariah atau Unit Usaha Syariah.

Perbankan syariah telah memberikan pengaruh yang signifikan pada praktik keuangan syariah lainnya, seperti asuransi syariah, obligasi syariah, reksadana syariah, perusahaan pembiayaan syariah, dan pasar modal syariah. Berkembangnya perbankan syariah dan sektor keuangan syariah lainnya, telah membentuk sistem ganda ekonomi di Indonesia yaitu ekonomi konvensional dan ekonomi syariah. ${ }^{12}$

Sampai dengan Oktober 2012, jumlah Bank Umum Syariah (BUS) berkembang menjadi 11 unit dan Unit Usaha Syariah (UUS) berjumlah 24 unit. Selain itu, pelayanan kebutuhan masyarakat akan perbankan syariah menjadi semakin meningkat tercermin dari bertambahnya Kantor Cabang (KC) dari sebelumnya sebanyak 452 menjadi 508 kantor. Sementara itu, Kantor Cabang Pembantu (KCP) dan Kantor Kas (KK) bertambah sebanyak 440 kantor. Secara keseluruhan jumlah kantor perbankan syariah yang beroperasi sampai dengan Oktober 2012 dibandingkan tahun sebelumnya meningkat dari 1.692 kantor menjadi 2.188 kantor. $^{13}$

Perkembangan perbankan syariah hingga bulan Oktober 2012 cukup menggembirakan. Aset perbankan syariah mampu berkembang $\pm 37 \%$ sehingga total asetnya mencapai Rp 174,09 triliun. Begitu pula dengan pembiayaan pada perbankan syariah jumlahnya mencapai Rp 135,58 triliun

\footnotetext{
${ }^{11}$ Syukri Iska, Sistem Perbankan Syariah di Indonesia dalam Perspektif Fikih Ekonomi, (Yogyakarta: Fajar Media Press, 2012), 252-253.

${ }^{12}$ A. Wangsawidjaja Z, Pembiayaan Bank Syariah (Jakarta: Gramedia Pustaka Utama, 2012), 10. Berdasarkan ketentuan Pasal I No. 2 tahun 2008 tentang Kompilasi Hukum Ekonomi Syariah, yang dimaksud dengan ekonomi syariah adalah usaha atau kegiatan yang dilakukan oleh orang per orang, kelompok orang, badan usaha yang berbadan hukum atau tidak berbadan hukum dalam rangka memenuhi kebutuhan yang bersifat komersial dan tidak komersial menurut prinsip syariah.

${ }^{13}$ Bank Indonesia, “Outlook Perbankan Syariah Tahun 2013” (Jakarta: Bank Indonesia, 2012), 1.
} 
(40,06\%, year on year) dan penghimpunan dana menjadi Rp.134,45 triliun $(32,06 \%)$. Strategi edukasi dan sosialisasi perbankan syariah melalui hubungan sinergi antara Bank Indonesia dengan industri dalam bentuk $i B$ campaign baik untuk pendanaan maupun pembiayaan mampu memperluas pangsa pasar perbankan syariah menjadi $\pm 4,3 \%{ }^{14}$

Pada akhir tahun 2012 pangsa pasar perbankan syariah di Indonesia mencapai 4,8\%. ${ }^{15}$ Meskipun meningkat, angka ini masih kalah dibandingkan dengan pangsa pasar perbankan syariah di negara-negara muslim lainnya. Malaysia yang memiliki pangsa pasar terbesar dibandingkan dengan negara lain, yaitu sebesar 19,98\% pada 2012, disusul Bahrain sebesar 12,82\%, dan Pakistan sebesar 8,60\%. Dalam hal ini, Malaysia mendapat dukungan penuh dari pemerintah sehingga perbankan syariah di Malaysia dapat tumbuh dengan pesat dibandingkan dengan perbankan syariah di Indonesia dan di negara lain. Khususnya di Indonesia, sistem perbankan masih menerapkan sistem perbankan ganda yang membuat persaingan semakin ketat di dunia perbankan.

Gambar 2. Komparasi Pertumbuhan Pangsa Pasar

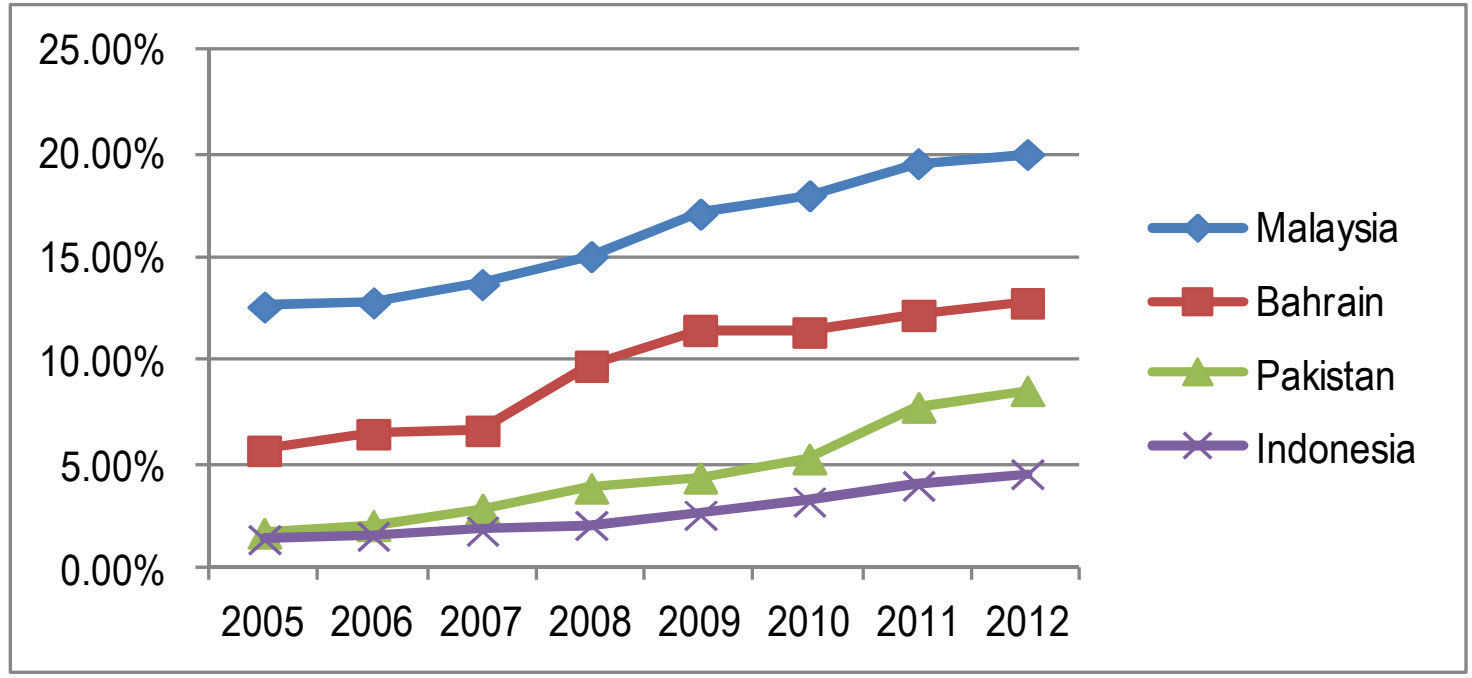

Sumber: Ascarya, 2013.

\footnotetext{
${ }^{14}$ Bank Indonesia, “Outlook Perbankan Syariah Tahun 2013”, 3.

${ }^{15}$ Meskipun tingkat perkembangan perbankan syariah nasional mencapai kemajuan cukup pesat, baik dari segi aset maupun jumlah kantor cabang, namun jika dibandingkan dengan pangsa pasar (market share) bank umum konvensional, pangsa pasar bank syariah masih sangat kecil. Lihat penjelasan dalam A. Wangsawidjaja Z, Pembiayaan Bank Syariah, 11.
} 
Bank Syariah adalah lembaga keuangan yang menggunakan sistem bagi

hasil. Konsep nisbah bagi hasil ditentukan pada awal berlakunya kontrak kerjasama sesuai dengan kesepakatan. Mekanisme sistem bagi hasil terdiri dari dua bentuk. Pertama, pembagian keuntungan yaitu bagi untung bersih dari keseluruhan pendapatan setelah dikeluarkan biaya-biaya. Kedua, pembagian pendapatan yaitu bagi hasil didasarkan pada keseluruhan pendapatan yang diterima sebelum dikeluarkan biaya-biaya untuk mendapatkannya. Secara umum yang diterapkan di Indonesia adalah pembagian pendapatan di mana bank sebagai pemodal (șâhibul mâl) dan nasabah sebagai pengguna dana (mud̂ârib). Dalam pembagian keuntungan bank berfungsi sebagai pengelola dana (mud̂ârib) dan nasabah sebagai penabung (șâhibul mâl). ${ }^{16}$

Pada kenyataan dalam perbankan syariah, di samping hal-hal positif baik dari segi jenis produk perbankan, prinsip operasional, dan rate of return, juga terdapat pembiayaan bermasalah (non performing financing atau NPF) dan kendala-kendala yang dikhawatirkan dapat menghambat laju perkembangan bank syariah di Indonesia. Kendala-kendala tersebut meliputi antara lain dalam bidang sarana keuangan (financial infrastructure), sumber daya manusia, sosialisasi, pendidikan, permodalan, dan peraturan. Permasalahan lain adalah dalam pengembangan dan inovasi produk. Setiap produk bank syariah harus mendapatkan persetujuan dari DSN-MUI sebelum diluncurkan dan inovasi produk tersebut sudah seharusnya mengikuti perkembangan zaman, budaya, dan teknologi. ${ }^{17}$

\section{Pertumbuhan Ekonomi dan Produk Domestik Bruto (PDB)}

Produk Domestik Bruto pada umumnya digunakan sebagai indikator baik buruknya perekonomian sebuah negara dan sebagai tolak ukur kesejahteraan masyarakat. Bagi para ekonom, ahli statistika, dan wartawan, perhitungan pendapatan nasional memberikan informasi mendalam yang dapat digunakan untuk memproyeksikan pertumbuhan dan pembangunan ekonomi. Walaupun perhitungan pendapatan nasional bukan merupakan ilmu

\footnotetext{
${ }^{16}$ Syukri Iska, Sistem Perbankan Syariah di Indonesia, 113-114.

${ }^{17}$ A. Wangsawidjaja Z, Pembiayaan Bank Syariah, 13 - 14.
} 
pasti, perhitungan tersebut memberikan kinerja ekonomi dan bagaimana produksi atau pendapatan dihasilkan dan dialokasikan. ${ }^{18}$

Nilai Produk Domestik Bruto (PDB) yang digunakan untuk mengukur pertumbuhan ekonomi adalah PDB berdasarkan harga konstan. Dalam hal ini, pengaruh perubahan harga telah dihilangkan, sehingga sekalipun angka yang muncul adalah nilai uang dari hasil keseluruhan barang dan jasa, perubahan nilai PDB juga menunjukkan perubahan jumlah kuantitas barang dan jasa yang dihasilkan selama periode pengamatan. ${ }^{19}$

PDB Indonesia nampak selalu memberikan prediksi optimistik yang meningkat dari tahun ke tahun. Berdasarkan laporan Badan Pusat Statistik (BPS) secara kumulatif PDB tumbuh 5,9\% per tahun 2010, lebih tinggi bila dibandingkan dengan capaian tahun 2009 pada periode yang sama, yaitu hanya sebesar 5,8\% saja. Cadangan devisa mencapai USD 94,7 miliar dan nilai ekspor mencapai USD 150 miliar. Angka pertumbuhan tersebut sepintas menunjukkan bahwa kinerja ekonomi Indonesia semakin baik. ${ }^{20}$

Tujuan utama perbankan syariah adalah mempercepat pertumbuhan ekonomi dalam kehidupan masyarakat. Untuk merealisasikannya, kegiatan perbankan harus terfokus pada kegiatan produksi. ${ }^{21}$ Pertumbuhan ekonomi penting dan dibutuhkan untuk mempersiapkan kemajuan perekonomian. Selain itu, pertumbuhan ekonomi juga penting untuk beberapa hal di bawah ini:

1. Peningkatan Kesejahteraan

Rakyat dikatakan semakin sejahtera jika setidak-tidaknya hasil per kapita meningkat. Tingkat kesejahteraan tersebut diukur dengan PDB per kapita. Agar PDB per kapita terus meningkat, maka perekonomian harus terus tumbuh dan harus lebih tinggi daripada tingkat pertumbuhan penduduk.

Strategi peningkatan kesejahteraan untuk seluruh rakyat menegaskan posisi rakyat adalah sentral-substansial (tahta milik rakyat) dan tidak boleh direduksi menjadi marjinal-residual (tahta untuk modal finansial).

\footnotetext{
${ }^{18}$ Mudrajad Kuncoro, Mudah Memahami dan Menganalisis Indikator Ekonomi (Yogyakarta: UPP STIM YKPN, 2013), 27.

${ }^{19}$ Prathama Rahardja dan Mandala Manurung, Teori Ekonomi Makro Suatu Pengantar (Jakarta: Lembaga Penerbit FE UI, 2008), 129.

${ }^{20}$ Muhammad Sri Wahyudi Suliswanto, "Pengaruh Produk Domestik Bruto (PDB) dan Indeks Pembangunan Manusia (IPM) Terhadap Angka Kemiskinan di Indonesia," Jurnal Ekonomi Pembangunan 8 No. 2 Desember (2010): 357.

${ }^{21}$ Said Sa'ad Marthon, Ekonomi Islam di Tengah Krisis Global (Jakarta: Zikrul Hakim, 2004), 135 .
} 
Pembangunan adalah dari rakyat, oleh rakyat, dan untuk rakyat. Rakyatlah yang dibangun. Dalam pembangunan ekonomi, rakyat menjadi prioritas sehingga strategi pembangunan yang harus diadopsi adalah pembangunan ke arah upaya memperluas kemampuan rakyat. ${ }^{22}$

Berkaitan dengan kesejahteraan, ekonomi syariah menjunjung tinggi kesejahteraan umum (mașlahah mursalah), yang dapat diartikan sebagai upaya untuk mendapatkan manfaat bagi kepentingan umum dan menghindarkan risiko. ${ }^{23}$ Maṣlahah (kesejahteraan) merupakan puncak dari maqạsid al-shari'ah atau tujuan diterapkannya prinsip syariah dalam lembaga keuangan syariah.

2. Kesempatan Kerja

Hubungan antara pertumbuhan ekonomi dengan kesempatan kerja dibahas oleh seorang ekonom bernama Arthur Okun. Menurut Okun, tingkat pengangguran yang minimal akan tercapai jika seluruh kapasitas produksi terpakai kesempatan kerja penuh.

Islam memandang aktivitas produksi merupakan bagian dari kewajiban untuk menciptakan kemakmuran semesta. Imam Al-Syaibani menegaskan bahwa kerja merupakan unsur utama produksi mempunyai kedudukan penting dalam kehidupan sebab menunjang pelaksanaan ibadah kepada Allah Swt. Maka, hukum bekerja adalah wajib. Dalam hal ini, negara berkewajiban untuk memimpin gerakan produktivitas nasional. ${ }^{24}$

3. Perbaikan Distribusi Pendapatan

Distribusi pendapatan yang baik adalah jika pendapatan semakin merata. Tetapi tanpa adanya pertumbuhan ekonomi, yang terjadi adalah pemerataan kemiskinan. Pertumbuhan ekonomi hanya akan menghasilkan perbaikan distribusi pendapatan jika memenuhi setidaktidaknya dua syarat, yaitu memperluas kesempatan kerja dan meningkatkan produktivitas. Jika kesempatan kerja tersedia, maka akses rakyat untuk memperoleh penghasilan semakin besar. ${ }^{25}$ Banyak bukti menunjukkan bahwa paket-paket program pengentasan kemiskinan di

${ }^{22}$ Sri Edi Swasono, Kembali ke Pasal 33 UUD 1945 Menolak Neoliberalisme (Jakarta: Yayasan Hatta, 2010), 134-135.

${ }^{23}$ A. Wangsawidjaja Z, Pembiayaan Bank Syariah, 28.

${ }^{24}$ Ridjaluddin Fadjar Noegraha, Nuansa-Nuansa Ekonomi Islam, 12-13.

${ }^{25}$ Rahardja dan Manurung, Teori Ekonomi Makro Suatu Pengantar, 132-135. 
Indonesia lebih banyak berorientasi pada peningkatan produksi daripada bertujuan untuk mendistribusikan pendapatan dan kesejahteraan. ${ }^{26}$

Mengenai distribusi pendapatan, ekonomi syariah memiliki satu prinsip yaitu keadilan distributif. Ekonomi syariah bertujuan untuk mensejahterakan masyarakat secara adil dan seimbang. Sebab, dengan landasan tersebut pihak yang terlibat dalam proses ekonomi tidak akan saling menindas atau mengeksploitasi satu sama lain. Melalui prinsip keadilan distributif, penumpukan kekayaan oleh sekelompok orang dihindari dan aliran kekayaan dapat merata kepada masyarakat yang lemah. Semua individu memiliki peluang yang sama untuk berusaha dan mengalokasikan pendapatannya secara efisien. Instrumen penting dalam proses keadilan distributif kekayaan adalah sistem bagi hasil. Melalui sistem ini dapat dibangun persaudaraan (brotherhood) dan kerja sama (cooperation) antara pemilik modal (șâhibul mâl) dengan pihak yang memiliki keahlian (mudârib) sehingga ada transfer kepemilikan aset dan distribusi pendapatan. ${ }^{27}$

\section{Peran Perbankan Syariah terhadap Pertumbuhan Ekonomi}

Hasil olah data sekunder time series quarterly (kuartalan) dari publikasi Badan Pusat Statistik (BPS) dan Bank Indonesia, berupa Produk Domestik Bruto (PDB) sebagai variabel dependen, total aset perbankan syariah (AST) dan total pembiayaan perbankan syariah (FINC) sebagai variabel independen, adalah:

$$
\begin{aligned}
& \mathrm{PDB}=14.31607-5.92006 \mathrm{AST}+6.04006 \mathrm{FINC} \\
& (0.24095) \quad(3.29006) \\
& \mathrm{R}^{2}=0.33875
\end{aligned}
$$

Tabel 1. Hasil Perkiraan Model

\begin{tabular}{|l|l|l|}
\hline Dependent Variable: PDB & & \\
\hline Method: Least Squares & & \\
\hline Date: 06/15/13 Time: 22:22 & & \\
\hline Sample: 2008Q1 2012Q4 & & \\
\hline
\end{tabular}

${ }^{26}$ Bagong Suyanto, "Kemiskinan dan Pemberdayaan Masyarakat Miskin," Jurnal Masyarakat, Kebudayaan, dan Politik XIV No. 4(2001): 38.

${ }^{27}$ Euis Amalia, Keadilan Distributif dalam Ekonomi Islam: Penguatan Peran LKM dan UKM di Indonesia (Jakarta: Raja Grafindo Persada, 2009), 357-358 dan 371. 


\begin{tabular}{|l|ll|l|l|}
\hline \multicolumn{3}{|l|}{ Included observations: 20} & & \\
\hline \hline Variale & Coefficient & Std. Error & t-Statistic & Prob. \\
\hline \hline C & 14.31607 & 0.240948 & 59.41551 & 0.0000 \\
\hline AST & -5.920006 & 3.290006 & -1.802752 & 0.0892 \\
\hline FINC & 6.040006 & 2.220006 & 2.718758 & 0.0146 \\
\hline
\end{tabular}

Sumber: Hasil Eviews (Econometric Views) versi 7.

Nilai $\mathrm{R}^{2}$ adalah $0.33875(33,8 \%)$ yang berarti bahwa variabel-variabel independen mampu menjelaskan pengaruhnya sebesar 33,8\% terhadap variabel dependen. Hasil dari hasil olah data dapat dianalisis bahwa variabel AST bertanda negatif $(-5.920006)$ berarti total aset bank syariah tidak berpengaruh secara signifikan terhadap PDB. Hal ini dikarenakan jumlah total aset bank syariah relatif kecil jika dibandingkan dengan total aset bank konvensional.

Jika variabel FINC naik sebesar 1\% maka PDB akan meningkat sebesar 6.040006 dengan catatan bahwa variabel lain dianggap konstan (cateris paribus). Penyaluran pembiayaan oleh bank syariah memberikan dampak positif terhadap PDB yang berarti bahwa pembiayaan oleh bank syariah berperan terhadap pertumbuhan ekonomi nasional meskipun masih sangat kecil.

Nilai probabilitas F-statistik adalah 0.029721 (2,97\%) dan lebih kecil dari $\alpha=5 \%(0,05)$ yang berarti bahwa variabel independen AST dan FINC secara bersama-sama memiliki pengaruh terhadap variabel dependen PDB. Uji t-statistik menghasilkan angka probabilitas variabel AST $(0,0892)$ yang lebih besar dari $\alpha=5 \%(0,05)$ dan berarti tidak memiliki pengaruh yang signifikan terhadap PDB. Sedangkan probabilitas variabel FINC $(0,0146)$ dan lebih kecil dari $\alpha=5 \%(0,05)$ yang berarti mempunyai pengaruh yang signifikan terhadap PDB.

Selanjutnya, mengapa peran perbankan syariah bagi pertumbuhan ekonomi belum signifikan? Jawaban yang mungkin adalah karena pangsa pasar perbankan syariah masih rendah dibandingkan dengan bank konvensional meskipun jumlah aset perbankan syariah terus meningkat. Pasar merupakan elemen penting dalam kegiatan ekonomi, produksi, dan distribusi. pangsa pasar yang kecil menyebabkan biaya produksi yang 
dibutuhkan sangat besar, dan mengakibatkan harga produk tidak kompetitif. Pangsa pasar yang terlalu sempit akan mematikan kegiatan investasi yang pada akhirnya menghambat pertumbuhan ekonomi ${ }^{28}$ Untuk itu, pangsa pasar menjadi kunci utama untuk meningkatkan kontribusi perbankan syariah terhadap pertumbuhan ekonomi nasional dan menghapus kesenjangan sosial.

\section{Revitalisasi Strategi Peningkatan Pangsa Pasar}

Salah satu solusi yang dapat diambil untuk meningkatkan kontribusi perbankan syariah terhadap pertumbuhan ekonomi Indonesia adalah dengan melakukan revitalisasi strategi untuk mendongkrak pangsa pasar. Beberapa strategi tersebut antara lain:

\section{Sumber Daya Insani}

Direktorat perbankan syariah Bank Indonesia merujuk data riset dari beberapa lembaga penelitian, menyatakan bahwa hampir 60\% Sumber Daya Insani (SDI) yang berada di bank syariah adalah dari bank konvensional. Mereka hanya sedikit diberikan pelatihan, dalam waktu singkat, dan langsung bertugas sebagai bankir syariah. Kondisi ini mengakibatkan pola fikir bankir yang terkadang konvensional. ${ }^{29}$

Berdasarkan riset yang dilakukan Universitas Indonesia tahun 2003 ditemukan bahwa $90 \%$ sumber daya manusia bank syariah tidak memiliki latar belakang pendidikan ekonomi syariah. Menurut Sofyan Syafri Harahap (Guru Besar Universitas Trisakti), sumber daya insani yang ada sekarang belum cukup, belum sesuai harapan, dan hanya pragmatis serta belum bisa mengubah ke situasi yang lebih baik atau yang sesuai nilai-nilai syariah. ${ }^{30}$

Jika SDI yang tidak memiliki latar belakang ekonomi syariah dipekerjakan di sektor perekonomian syariah, kekhawatiran masyarakat terhadap perekonomian syariah 'ternyata sama saja' dengan sistem perekonomian konvensional, akan mungkin dapat terwujud. Untuk mengatasi hal ini, program-program pendidikan dan pelatihan sistem ekonomi syariah bagi SDI dapat diberikan kepada alumni PTN dan PTS. Tujuannya adalah

\footnotetext{
${ }^{28}$ Said Sa'ad Marthon, Ekonomi Islam di Tengah Krisis Global (Jakarta: Zikrul Hakim, 2004), 143-144.

${ }^{29}$ Redaksi Laporan Utama, "Dicari Bankir Syariah yang Komunikatif”, Sharing: Majalah Ekonomi dan Syariah, Juli 2008, Edisi 19, 10.

${ }^{30} \mathrm{M}$. Nur Rianto Al-Arif, Dasar-Dasar Ekonomi Islam (Solo: Era Adicitra Intermedia, 2011), 324-325.
} 
agar sharia compliance dapat dilaksanakan dengan baik dan keahlian mengenai perbankan syariah dapat terus diasah. ${ }^{31}$

SDI dalam perbankan syariah harus memiliki pengetahuan yang luas di bidang perbankan, memahami praktik-praktik syariah di perbankan, serta memiliki komitmen kuat untuk menerapkannya secara konsisten. Pengembangan SDI di bidang perbankan syariah sangat perlu sebab keberhasilan perbankan syariah sangat ditentukan oleh kualitas manajemen, tingkat pengetahuan dan keterampilan pengelola bank. ${ }^{32}$ Selain itu, SDI merupakan aset yang sangat berharga bagi organisasi. Kemampuan untuk mengelola sumber daya insani, berupa pemberdayaan karyawan, akan dapat meningkatkan komitmen karyawan terhadap organisasi. Karyawan yang komitmen akan memberikan dampak yang besar terhadap pencapaian kinerja organisasi. Komitmen karyawan menunjukkan adanya kepuasan karyawan terhadap organisasinya, sehingga jika karyawan puas, maka akan mampu memberikan dan meningkatkan kepuasan konsumen. Apabila kepuasan konsumen tercapai maka organisasi akan mencapai pencapaian yang tinggi. ${ }^{33}$

Pelatihan penting untuk dilakukan agar peserta dapat mencapai suatu standar, baik dalam keterampilan, pengetahuan, maupun tingkah laku. Pelatihan tidak hanya untuk karyawan baru saja, karena setiap jenjang jabatan memerlukan pengetahuan dan keterampilan khusus. Oleh karena itu, setiap kali perlu melakukan pelatihan dalam bentuk di tempat kerja, di luar tempat kerja, lokakarya, atau kursus pendek. Pelatihan perlu untuk meningkatkan kualitas kerja, menghadapi persaingan global, dan menghadapi teknologi yang terus berkembang. ${ }^{34}$

Bank wajib memberikan pelatihan tentang prinsip 'Mengenal Nasabah' kepada semua karyawan, yang pelaksanaannya disesuaikan dengan kebutuhan bank. Bank juga wajib memberikan pelatihan secara berkala dan berkesinambungan untuk menjamin karyawan selalu memperoleh pengetahuan dan informasi terkini serta untuk mengkaji ulang kasus-kasus

\footnotetext{
${ }^{31}$ Safaah Restuning Hayati, "Menciptakan dan Mengoptimalkan Sumber Daya Insani," Makalah Forum Riset Perbankan Syariah (FRPS) ke-IV Bank Indonesia dan IAEI, (Bandung: UNPAD, 2012), 13-14.

${ }^{32}$ Muhammad Syafi'i Antonio, Bank Syariah dari Teori ke Praktik (Jakarta: Gema Insani, 2005), Cet. 5, 226.

${ }^{33}$ Siswanto, "Pengembangan Kualitas SDM Perbankan Syariah Integratif Melalui Implementasi Workplace Spirituality," Makalah pada The $2^{\text {nd }}$ Islamic Economics and Finance Research Forum (2013): 2.

${ }^{34}$ Jusmaliani, Pengelolaan Sumber Daya Insani (Jakarta: Bumi Aksara, 2011), 102.
} 
transaksi keuangan yang mencurigakan dan bermasalah. Untuk menentukan jenis pelatihan yang dibutuhkan, bank perlu memperhatikan kelompok karyawan yang membutuhkan pelatihan khusus, antara lain petugas front liner, petugas back office, dan pegawai baru. ${ }^{35}$ Pertumbuhan jangka panjang keuangan Islam membutuhkan pengembangan kerangka untuk mengembangkan SDI, mendorong aktivitas penelitian dan meningkatkan fasilitas pelatihan serta pendidikan dengan berkolaborasi bersama akademik dan institusi penelitian ternama. ${ }^{36}$

Program pelatihan dan pengembangan memiliki peran strategis untuk mengembangkan keterampilan dan keahlian SDI perbankan syariah, disamping meningkatkan pemenuhan kebutuhan spiritualitas di tempat kerja. Beberapa perbankan syariah dikembangkan dari perbankan konvensional melalui sistem dua jendela, dan sebagian yang lain sejak awal murni fokus pada sistem perbankan syariah. Hal ini memiliki konsekuensi dalam pengelolaan manajemen dan budaya organisasi. Walaupun demikian, secara bertahap perbankan syariah mempunyai komitmen untuk mengembangkan model manajemen dan budaya organisasi yang unik dan khas. Sistem syariah memiliki implikasi pada perubahan sikap dan perilaku karyawan dari organisasi yang menerapkannya. SDI atau pegawai yang sebelumnya berasal dari lingkungan perbankan konvensional berangsur-angsur mempraktikkan nilai-nilai islami dalam kehidupannya seiring dengan aktifnya di perbankan syariah. $^{37}$

\section{Peraturan}

Berbeda dengan negara-negara dengan mayoritas penduduk Muslim yang lain, di mana kemunculan sistem ekonomi syariah mendapat dukungan penuh dari pemerintah khususnya dalam bentuk regulasi, kehadiran bank syariah di Indonesia pada awalnya tidak sepenuhnya mendapat perhatian pemerintah. Terbukti dari dikeluarkannya Undang-Undang tentang

\footnotetext{
${ }^{35}$ Veithzal Rivai dan Rifki Ismail, Islamic Risk Management for Islamic Banking: Risiko Bukan untuk Ditakuti, tapi Dihadapi dengan Cerdik, Cerdas, dan Professional (Jakarta: Gramedia Pustaka Utama, 2013), 425 - 426.

${ }^{36}$ Muhammad Ayub, Understanding Islamic Finance: A-Z Keuangan Syariah, terj. Wisnu Pribadi (Jakarta: Gramedia Pustaka Utama, 2009), 729.

${ }^{37}$ Siswanto, "Pengembangan Kualitas SDM Perbankan Syariah Integratif Melalui Implementasi Workplace Spirituality," Makalah The $2^{\text {nd }}$ Islamic Economics and Finance Research Forum (2013): 13 - 14.
} 
Perbankan Syariah yaitu UU No. 21 Th. 2008 setelah 16 tahun bank syariah berdiri di Indonesia.

Lahirnya Undang-Undang No 21 Tahun 2008 tersebut membuat perbankan syariah semakin kuat karena memiliki payung hukum dalam operasional. Diharapkan dengan lahirnya undang-undang target penguasaan pangsa pasar perbankan syariah sebesar 5\% segera tercapai. Harapan selanjutnya, perbankan syariah mampu memiliki penguasaan pangsa pasar yang seimbang dengan perbankan konvensional. ${ }^{38}$

Di sektor mikro, status kelembagaan atau badan hukum BMT hingga saat ini adalah koperasi. Hal ini berarti kelembagaan BMT tunduk kepada Undang-Undang Perkoperasian No. 25 Th. 1992 dan secara spesifik diatur dalam Keputusan Menteri Negara Koperasi dan UKM RI No.91/Kep/M.KUKM/IX/2004 tentang Petunjuk Pelaksanaan Usaha Koperasi Jasa Keuangan Syariah (KJKS). Oleh karenanya, BMT belum memiliki regulasi tersendiri padahal sudah menjadi keniscayaan bahwa pesatnya aktivitas ekonomi masyarakat berbasis syariah diimbangi dengan regulasi yang mandiri. ${ }^{39}$ Peraturan yang berlaku belum sepenuhnya mengakomodasi operasional bisnis di perbankan syariah mengingat adanya sejumlah berbedaan dengan bisnis di perbankan konvensional. Ketentuanketentuan yang ada masih perlu disesuaikan agar memenuhi ketentuan syariah. Sehingga bisnis di perbankan syariah dapat beroperasi dengan efisien. Beberapa ketentuan tersebut antara lain instrumen moneter yang sesuai dengan prinsip syariah, ketentuan yang mengatur tentang prinsip kehati-hatian dan standar akuntansi, pengawasan, serta kebijakan perpajakan. $^{40}$

\section{Teknologi}

Perkembangan teknologi informasi telah mempengaruhi kebijakan dan strategi dunia usaha perbankan yang selanjutnya lebih mendorong inovasi dan persaingan di bidang layanan, terutama jasa layanan pembayaran melalui bank yang terus berkembang mengikuti pola kebutuhan nasabah bank.

\footnotetext{
${ }^{38}$ M. Nur Rianto Al-Arif, Dasar-Dasar Ekonomi Islam (Solo: Era Adicitra Intermedia, 2011), 314-315.

${ }^{39}$ Amalia, Keadilan Distributif dalam Ekonomi Islam, 242-243.

${ }^{40}$ Veithzal Rivai dan Antoni Nizar Usman, Islamic Economics and Finance: Ekonomi dan Keuangan Islam Bukan Alternatif, tetapi Solusi (Jakarta: Gramedia Pustaka Utama, 2012), 478.
} 
Transaksi perbankan berbasis elektronik dan internet misalnya, merupakan salah satu bentuk pengembangan penyediaan jasa layanan bank yang memberi peluang usaha baru. Hal ini berakibat pada perubahan strategi usaha perbankan berbasis manusia menjadi berbasis teknologi informasi yang lebih efisien bagi bank dan praktis bagi nasabah. ${ }^{41}$

Bank syariah harus mampu mengadaptasi berkembangnya teknologi yang semakin canggih, tentu dalam batas ketentuan syariah. ${ }^{42}$ Semakin ketatnya persaingan di dunia perbankan, bank syariah harus menggunakan teknologi secara optimal guna meningkatkan pangsa pasar. Salah satu solusinya adalah bersinergi dengan bank induk dalam penggunaan teknologi.

Teknologi berguna bagi pengembangan jaringan perbankan syariah, terutama ditujukan untuk menyediakan akses yang lebih luas kepada masyarakat untuk mendapatkan layanan bank syariah. Selain itu, teknologi sangat penting dalam bidang pemasaran dan kegiatan sosialisasi kepada masyarakat. ${ }^{43}$ Pengembangan jaringan bisnis menjadi hal penting sebab dapat meningkatkan efisiensi usaha, meningkatkan kualitas pelayanan, dan mendorong inovasi produk dan jasa perbankan syariah. Salah satu cara untuk mengembangkan jaringan bisnis adalah dengan pembukaan kantor cabang syariah. $^{44}$

Pengenalan dan penguasaan teknologi informasi, sistem gudang data, penguasaan piranti keras dan piranti lunak merupakan suatu hal yang penting bagi pengelola dan staf, terutama untuk operasional produk dan pembuatan laporan keuangan sesuai dengan pedoman yang ada. Dukungan teknologi yang baik dan tepat akan sangat membantu administrasi dan manajemen yang baik. ${ }^{45}$

\section{Kontribusi Pembiayaan Mudâarabah dan Murâbahah}

Masalah lain yang muncul dalam pembiayaan perbankan syariah adalah konstribusi yang sangat sedikit terhadap pertumbuhan ekonomi nasional. Hal ini disebabkan oleh alokasi pembiayaan masih didominasi oleh pembiayaan murâbahah sedangkan pembiayaan muḍâabah dengan sistem

\footnotetext{
${ }^{41}$ Rivai dan Ismail, Islamic Risk Management for Islamic Banking, 427.

${ }^{42}$ Karnaen A. Perwataatmadja dan Hendri Tanjung, Bank Syariah: Teori, Praktik, dan Peranannya (Jakarta: Celestial Publishing, 2007), 207.

${ }^{43}$ Muhammad Syafi'i Antonio, Bank Syariah dari Teori ke Praktik, 229.

${ }^{44}$ Rivai dan Usman, Islamic Economics and Finance, 480-481.

${ }^{45}$ Euis Amalia, Keadilan Distributif dalam Ekonomi Islam, 218.
} 
bagi hasil masih relatif kecil. Padahal, berdasarkan prinsip ekonomi syariah, sebuah pembiayaan harusnya disalurkan lebih besar ke sektor produktif (muḷârabah) bukan ke sektor konsumtif (murâbahah). Pembiayaan yang disalurkan bank syariah pada dasarnya dapat digunakan untuk pembiayaan modal kerja, investasi, dan pembiayaan konsumsi. Rincian penggunaan pembiayaan Bank Umum Syariah (BUS) dan Unit Usaha Syariah (UUS) per Desember 2011 dalam miliar rupiah, yaitu modal kerja sebesar 41,698 (40,62\%), investasi sebesar 17,903 (17,44\%), dan konsumsi 43,053 (41,94\%). Sayangnya, penyaluran pembiayaan tersebut tampak presentase pembiayaan konsumtif masih cukup tinggi jika dibandingkan dengan porsi lainnya, yaitu $41,94 \%$. Idealnya, pembiayaan yang diberikan oleh perbankan syariah lebih banyak untuk sektor produktif atau berdasarkan akad mudârabah dan mushârakah, karena lebih sesuai dengan prinsip syariah: pembagian untung dan rugi (PLS). Melalui pembiayaan mudârabah dan mushârakah tersebut diharapkan dapat lebih mendorong peningkatan dalam sektor nyata (produksi barang) seperti pertanian, pertambangan, dan industri serta sektor non riil seperti perdagangan dam jasa-jasa. Hingga per Desember 2011, pembiayaan yang diberikan perbankan syariah lebih banyak disalurkan ke sektor lain-lain (non produktif) yaitu sebesar $42,05 \%$, sedangkan untuk sektor pertanian dan kehutanan 2,14\% serta sektor pertambangan $1,65 \%{ }^{46}$

Berbagai alasan yang mendasari minimnya pembiayaan mudârabah telah banyak dikemukakan. Salah satunya adalah risiko yang tinggi dan keuntungan yang kurang. Alasan yang lain adalah mudârabah sebagai bentuk pembiayaan, realitasnya sedikit sekali. Hal ini disebabkan karena sulitnya pihak bank melaksanakan pengawasan dan mencari muḍ̂arib yang jujur. Konsekuensi akad mudârabah dengan pola bagi hasil adalah diperlukan kejujuran. ${ }^{47}$

Bank syariah seharusnya didominasi oleh produk berbasis bagi hasil dengan fokus kepada pembiayaan daripada memberikan pinjaman atau kredit. Pembiayaan dengan sistem bagi hasil memiliki visi pertumbuhan ekonomi, memilih proyek yang berpotensi baik, memonitori investasi secara dekat, dan menyalurkan risiko dari aset kepada liabilitas untuk kestabilan bank. ${ }^{48}$ Hal ini juga sesuai dengan tujuan pembiayaan bank syariah, yaitu

\footnotetext{
${ }^{46}$ A. Wangsawidjaja Z, Pembiayaan Bank Syariah, 231 - 234.

${ }^{47}$ Syukri Iska, Sistem Perbankan Syariah di Indonesia dalam Perspektif Fikih Ekonomi, 324.

${ }^{48}$ Imam Wahyudi dkk, Manajemen Risiko Bank Islam, 233.
} 
untuk menunjang pelaksanaan pembangunan nasional dalam rangka meningkatkan keadilan, kebersamaan, dan pemerataan kesejahteraan rakyat. ${ }^{49}$ Statistik perbankan syariah pada Februari 2012 menunjukkan skim pembiayaan mudârabah di perbankan syariah lebih kecil dibandingkan dengan pembiayaan murâbahah.

Tabel 2. Pembiayaan BUS dan UUS

\begin{tabular}{|c|c|c|c|c|c|}
\hline Pembiayaan & \multicolumn{5}{|c|}{ Tahun [miliar rupiah] } \\
\hline Akad & $\mathbf{2 0 0 8}$ & $\mathbf{2 0 0 9}$ & $\mathbf{2 0 1 0}$ & $\mathbf{2 0 1 1}$ & $\mathbf{2 0 1 2}$ \\
\hline Mự̂âabahh & 6.205 & 6.597 & 8.631 & 10.229 & 10.122 \\
\hline Murâbahahah & 22.486 & 26.321 & 37.507 & 56.365 & 58.326 \\
\hline
\end{tabular}

Sumber: Bank Indonesia, Februari 2012.

Sekilas, sangat terlihat bahwa pembiayaan dengan sistem bagi hasil (muḍarabah) masih kecil jika dibandingkan dengan pembiayaan yang dialokasikan melalui murâbahah. Pada tahun 2012, pembiayaan murâbahah lebih besar lima kali lipat daripada bagi hasil (muḍarabah).

Prinsip bagi hasil merupakan karakteristik umum dan landasan dasar bagi operasional bank syariah secara keseluruhan. Secara syariah, prinsip tersebut berdasarkan kaidah muḍârabah. Dalam prinsip ini bank syariah berfungsi sebagai mitra, baik dengan penabung maupun dengan pengusaha yang meminjam dana. Dengan penabung, bank syariah bertindak sebagai pengelola (muḍarib), sedangkan penabung bertindak sebagai pemilik modal (șâhibul mâl). ${ }^{50}$ Porsi alokasi pembiayaan bagi hasil lebih jelas dapat dilihat dalam tabel berikut:

Tabel 3. Porsi Pembiayaan Bagi Hasil dan Murâbahah

\begin{tabular}{|l|l|l|l|l|l|}
\hline \multicolumn{1}{|c|}{ Pembiayaan } & \multicolumn{5}{|c|}{ Tahun } \\
\hline \multicolumn{1}{|c|}{ Akad } & \multicolumn{1}{|c|}{2008} & 2009 & 2010 & 2011 & 2012 \\
\hline Bagi Hasil & $36 \%$ & $36 \%$ & $34 \%$ & $28 \%$ & $28 \%$ \\
\hline Murâbahah & $59 \%$ & $56 \%$ & $55 \%$ & $55 \%$ & $56 \%$ \\
\hline Lain-Lain & $5 \%$ & $8 \%$ & $11 \%$ & $17 \%$ & $15 \%$ \\
\hline
\end{tabular}

\footnotetext{
${ }^{49}$ Pasal 3 Undang-Undang Perbankan Syariah dalam A. Wangsawidjaja Z, Pembiayaan Bank Syariah, 235.

${ }^{50}$ Muhammad Syafi'i Antonio, Bank Syariah dari Teori ke Praktik, 137.
} 
Sumber: Hendri, 2013. ${ }^{51}$

Tabel tersebut menunjukkan bahwa porsi murâbahah pada Februari 2012 dua kali lipat porsi pembiayaan bagi hasil. Meskipun porsi bagi hasil pada 2008 dan 2009 stabil, tetapi pada 2010 mengalami penurunan sebesar 2\% dan terus menurun hingga tahun 2012 menjadi $28 \%$.

Tabel 4. Penyaluran Dana BUS dan UUS hingga Oktober 2012

(dalam Triliun Rupiah)

\begin{tabular}{|c|c|c|}
\hline \multirow{2}{*}{ Pembiayaan } & \multicolumn{2}{|c|}{ Pertumbuhan (Growth) } \\
\hline & Nominal & Share (\%) \\
\hline Muḍârabah & 11,44 & 8,44 \\
\hline Murâbahah & 80,95 & 59,71 \\
\hline Qard & 11,19 & 8,25 \\
\hline
\end{tabular}

Sumber: Fahmi Faisal, 2013.

Berdasarkan tabel di atas, terlihat jelas bahwa penyaluran dana melalui skim mudârabah sangat sedikit dibandingkan skim murâbahah. Realitas ini tidak sejalan dengan teori yang mengatakan bahwa tujuan bank syariah adalah mendorong dan mempercepat kemajuan ekonomi suatu negara melalui sektor riil melalui pembiayaan berbasis bagi hasil. Perlu usaha lebih dari bank syariah untuk lebih memaksimalkan pembiayaan berdasar bagi untungruginya agar dapat memenuhi hakikat bank syariah yang bertujuan untuk meningkatkan sektor riil. ${ }^{52}$

Berdasarkan hasil penelitian yang dikemukakan oleh Adiwarman, bagi hasil (mudârabah) tidak begitu berkembang pelaksanaannya di bank-bank syariah dengan beberapa alasan, yaitu sebagian besar sumber dana bank syariah berjangka waktu pendek sehingga sulit digunakan untuk pembiayaan bagi hasil. Selain itu, pengusaha besar tidak begitu tertarik dengan sistem

\footnotetext{
${ }^{51}$ Hendri Tanjung dan Abrista Devi, Metodologi Penelitian Ekonomi Islam (Jakarta: Gramata Publishing, 2013), 201.

${ }^{52}$ Ryantiar Fahmi Faisal, "Peran Pembiayaan Bank Syariah Terhadap Pengembangan Sektor Riil," Jurnal Ilmiah Ilmu Ekonomi Fakultas Ekonomi dan Bisnis Universitas Brawijaya Malang (2013): 4.
} 
bagi hasil karena kredit bank konvensional menawarkan bunga yang lebih menguntungkan dan lebih pasti. ${ }^{53}$

Transaksi murâbahah dalam beberapa tahun terakhir lebih banyak digunakan di perbankan syariah dibandingkan dengan skim lain karena skim murâbahah mudah dipahami dan diterapkan tanpa perlu mengenal nasabah secara mendalam. Dalam penerapannya, murâbahah hampir sama dengan kredit investasi konsumtif dalam bank konvensional, walaupun hakikatnya merupakan dua hal yang jauh berbeda. Pendapatan bank dalam transaksi murâbahah dapat diprediksi karena utang nasabah adalah harga jual yang terkandung di dalam harga pokok dan keuntungan yang telah dipastikan sejak awal transaksi. ${ }^{54}$

Terkait dengan pembiayaan muḍarabah untuk sektor mikro, hasil riset Putrina Sari (2013) menyimpulkan bahwa salah satu cara yang dapat dilakukan oleh perbankan syariah dalam mendukung keuangan inklusif adalah dengan meningkatkan pembiayaan terhadap sektor mikro. Secara keseluruhan permasalahan yang menjadi prioritas menurut praktisi dan pakar adalah: 1) proses pembiayaan; 2) pembiayaan mikro; 3) keuangan usaha mikro; 4) manajemen mikro; dan 5) lain-lain. Secara rinci, lima prioritas permasalahan menurut para pakar dan praktisi adalah: 1) akses sulit; 2) administrasi lama; 3) kualitas SDM rendah; 4) jaminan; dan 5) pencairan lama. Prioritas strategi untuk mengatasi permasalahan tersebut, secara keseluruhan menurut praktisi dan pakar adalah: 1) strategi teknis; 2) strategi fundamental; dan 3) strategi eksternal. Secara rinci, lima prioritas strategi menurut praktisi dan pakar adalah: 1) produk keuangan yang inovatif; 2) perbaikan akses pasar; 3) linkage program; 4) persiapan SDM bermutu; dan 5) perbanyak cabang. ${ }^{55}$

Nedal El-Ghattis ${ }^{56}$ dalam risetnya membuat penggolongan instrumen dalam perbankan Islam sesuai kontribusinya bagi pertumbuhan ekonomi, sebagai berikut:

\footnotetext{
${ }^{53}$ Syukri Iska, Sistem Perbankan Syariah di Indonesia dalam Perspektif Fikih Ekonomi (Yogyakarta: Fajar Media Press, 2012), 69.

${ }^{54}$ Syukri Iska, Sistem Perbankan Syariah di Indonesia, 85.

${ }^{55}$ Aisha Putrina Sari dkk, "Strategi Pembiayaan Perbankan Syariah dalam Mendukung Keuangan Inklusif Bagi Sektor Mikro Melalui Pendekatan ANP (Analytic Network Process)", Makalah The $2^{\text {nd }}$ Islamic Economics and Finance Research Forum (2013):13.

${ }^{56}$ Nedal El-Ghattis, "Islamic Banking's Role in Economic Development."
} 
Tabel 5. Kontribusi Pembiayaan Perbankan Syariah bagi Pertumbuhan

Ekonomi

\begin{tabular}{|l|c|c|c|}
\hline Corak Keuangan & $\begin{array}{l}\text { Pengawasan } \\
\text { Kemiskinan }\end{array}$ & $\begin{array}{l}\text { Pengawasan } \\
\text { Pengangguran }\end{array}$ & $\begin{array}{l}\text { Pengawasan } \\
\text { Inflasi }\end{array}$ \\
\hline Murâbahah & $\mathrm{x}$ & $\mathrm{x}$ & $\mathrm{x}$ \\
\hline Muḍ̂arabah & $\sqrt{ }$ & $\sqrt{ }$ & $\sqrt{ }$ \\
\hline Istithnâ & $\sqrt{ }$ & $\sqrt{ }$ & $\mathrm{x}$ \\
\hline Salâm & $\sqrt{ }$ & $\sqrt{ }$ & $\mathrm{x}$ \\
\hline Mushârakah & $\sqrt{ }$ & $\sqrt{ }$ & $\mathrm{V}$ \\
\hline Ijârah & $\mathrm{x}$ & $\mathrm{x}$ & $\mathrm{x}$ \\
\hline
\end{tabular}

Sumber: El-Ghattis, 2013.

Ada kemungkinan beralihnya fungsi bank Islam sebagai agen intermediasi menjadi bank investasi Islam. Sebagai bank investasi Islam, akan lebih leluasa jika menerapkan skim bagi hasil dalam operasionalnya. Ini sesuai dengan bisnis dasar yang seharusnya dijalankan oleh bank Islam. Sesuai dengan profilnya, bisnis dengan skema bagi hasil adalah resiko tinggi, tapi pengembaliannya juga tinggi. Infrastruktur yang harus segera dibangun adalah sistem informasi untuk meminimalkan biaya serta waktu, dan SDM untuk pengawasan. ${ }^{57}$

Upaya untuk mengantisipasi risiko penyaluran dana nasabah yaitu bank syariah harus menerapkan prinsip kehati-hatian, memelihara kesehatan, dan meningkatkan daya tahan. Bank syariah diwajibkan menyebar risiko dengan mengatur penyaluran pembiayaan berdasarkan prinsip syariah, pemberian jaminan atau fasilitas lain, sehingga tidak berpusat pada nasabah debitur atau kelompok nasabah debitur tertentu. Untuk mengurangi risiko pembiayaan yang dapat disebabkan oleh berbagai faktor, maka penanggulangan pembiayaan bermasalah dapat dilakukan melalui upayaupaya yang bersifat preventif, seperti wajib melakukan penilaian dengan saksama terhadap watak, kemampuan, modal, agunan, dan prospek usaha. Bank syariah juga dapat melakukan upaya-upaya penanggulangan pembiayaan bermasalah yang bersifat represif atau kuratif, ${ }^{58}$ seperti sanksi administratif dan sanksi pidana bagi nasabah yang melanggar ketentuan. ${ }^{59}$

\footnotetext{
${ }^{57}$ Imam Wahyudi dkk, Manajemen Risiko Bank Islam, 230.

${ }^{58}$ Upaya penanggulangan yang bersifat represif atau kuratif adalah upaya penanggulangan yang bersifat penyelamatan dan penyelesaian terhadap pembiayaan bermasalah (non performing financings/NPF).

${ }^{59}$ A. Wangsawidjaja Z, Pembiayaan Bank Syariah, 94 - 103.
} 
Suatu kontrak mudârabah digunakan dalam perbankan syariah untuk tujuan dagang jangka pendek dan suatu kongsi khusus. Bank-bank syariah mempraktikkan muḍârabah dengan sangat hati-hati. Sebab, bank jarang menemukan orang yang terpercaya. ${ }^{60}$ Tanjung dan Devi (2013) mencoba memberikan solusi untuk meningkatkan porsi pembiayaan dengan bagi hasil di perbankan syariah, yaitu dengan cara mempekerjakan orang dalam perusahaan yang dibiayai dengan skim bagi hasil. Orang tersebut menjadi wakil bank syariah dan dalam mu'âmalah hal ini biasa disebut dengan wakâlah. Wakil tersebut dapat mewakili bank syariah dan bertanggungjawab terhadap pembiayaan yang diberikan kepada klien sama seperti tanggung jawab bank syariah terhadap kliennya. ${ }^{61}$

Apabila strategi di atas dapat diterapkan, maka daya serap tenaga kerja di dunia perbankan syariah sangat besar dan hal ini dapat mengurangi angka pengangguran di Indonesia. Secara tidak langsung, meningkatnya angka kesempatan kerja akan membantu pemerataan pembagian pendapatan. Pada akhirnya tujuan akhir yang akan dicapai adalah meningkatkan angka kesejahteraan masyarakat dan pertumbuhan ekonomi agar semakin membaik.

\section{Kesimpulan}

Hasil uji model regresi menemukan bahwa total aset perbankan syariah tidak berpengaruh signifikan terhadap PDB sedangkan total pembiayaan perbankan syariah berpengaruh signifikan (positif) terhadap PDB. Variabel total aset dan total pembiayaan bank syariah mampu menjelaskan pengaruhnya sebesar $33,8 \%$ terhadap variabel PDB. Hal ini berarti bahwa peran perbankan syariah bagi pertumbuhan ekonomi relatif masih kecil. Pengaruh yang relatif kecil ini disebabkan oleh market share perbankan syariah yang masih kecil dan pembiayaan di bank syariah yang masih didominasi oleh murâbahah (sektor konsumtif). Padahal, karakteristik bank syariah terletak pada sistem bagi hasil (mudârabah) dengan sistem bagi untung dan rugi dan fokus kepada pembiayaan produktif.

Strategi yang dapat dilakukan oleh perbankan syariah untuk meningkatkan pangsa pasar antara lain dengan peningkatan kualitas dan kuantitas sumber daya insani, memperkuat regulasi, dan mengadaptasi berkembangnya teknologi yang semakin canggih. Selanjutnya, perbankan

\footnotetext{
${ }^{60}$ Abdullah Saeed, Menyoal Bank Syariah: Kritik atas Interpretasi Bunga Bank Kaum Neo-Revivalis, terj. Arif Maftuhin (Jakarta: Paramadina, 2006), 104.

${ }^{61}$ Hendri Tanjung dan Abrista Devi, Metodologi Penelitian Ekonomi Islam, 203.
} 
syariah harus meningkatkan pembiayaan dengan skim bagi hasil (mudâarabah) karena skim ini sudah terbukti mampu mengurangi kemiskinan, pengangguran, dan mengawasi inflasi.

\section{Daftar Pustaka}

Abduh, Muhammad dan Mohd Azmi Omar. "Islamic Banking And Economic Growth: The Indonesian Experience." International Journal of Islamic and Middle Eastern Finance and Management 5 No. 1 (2012): 35-47.

Abduh, Muhammad dan Nazreen T. Chowdhury. "Does Islamic Banking Matter for Economic Growth in Bangladesh?" Journal of Islamic Economics, Banking and Finance 8 No. 3 (2012): 104-113.

Amalia, Euis. Keadilan Distributif dalam Ekonomi Islam: Penguatan Peran LKM dan UKM di Indonesia. Jakarta: Raja Grafindo Persada, 2009.

Amin, Ahmad Riawan Amin. "Kita Harus Beralih ke Sistem Ekonomi Syariah." Sharing: Majalah Ekonomi dan Bisnis Syariah, edisi 23, November 2008.

Antonio, Muhammad Syafi'i. Bank Syariah dari Teori ke Praktik. Jakarta: Gema Insani, 2005.

Ariefianto, Moch. Doddy. Ekonometrika Esensi dan Aplikasi dengan Menggunakan Eviews. Jakarta: Erlangga. 2012.

Ascarya. Akad dan Produk Bank Syariah. Jakarta: Rajawali Press, 2007.

Ascarya. "Peran Riset untuk Mendukung Kebijakan Pemerintah dalam

Pengembangan Ekonomi Islam dan Bisnis Syariah." Makalah dipresentasikan dalam Seminar Nasional IAEI. Bogor: STEI Tazkia, 2013.

Ayub, Muhammad. Understanding Islamic Finance: A-Z Keuangan Syariah. Terj. Wisnu Pribadi. Jakarta: Gramedia Pustaka Utama, 2009.

Bank Indonesia. "Outlook Perbankan Syariah Tahun 2013”. Jakarta: Bank Indonesia, 2012.

Chapra, Muhammad Umer. Masa Depan Ilmu Ekonomi: Sebuah Tinjauan Islam, Terj. Ikhwan Abidin Basri. Jakarta: Gema Insani Press, 2001.

Faisal, Ryantiar Fahmi Faisal. "Peran Pembiayaan Bank Syariah Terhadap Pengembangan Sektor Riil.” Jurnal Ilmiah Ilmu Ekonomi Fakultas Ekonomi dan Bisnis Universitas Brawijaya Malang (2013): 4.

El-Ghattis, Nedal. "Islamic Banking's Role in Economic Development: Future Outlook". Diunduh dari http:// www.cba.edu.kw/wtou/ download/conf4/nedal.pdf tanggal 14 Juli 2013.

Hasan, Hasbi. Pemikiran dan Perkembangan Hukum Ekonomi Syariah di Dunia Islam Kontemporer. Depok: Gramata Publishing, 2011. 
Hayati, Safaah Restuning. "Menciptakan dan Mengoptimalkan Sumber Daya Insani." Makalah Forum Riset Perbankan Syariah (FRPS) ke-IV Bank Indonesia \& IAEI. Bandung: 2012.

Iska, Syukri. Sistem Perbankan Syariah di Indonesia dalam Perspektif Fikih Ekonomi. Yogyakarta: Fajar Media Press, 2012.

Jusmaliani. Pengelolaan Sumber Daya Insani. Jakarta: Bumi Aksara, 2011.

Kuncoro, Mudrajad. Metode untuk Bisnis dan Ekonomi. Jakarta: Erlangga, 2003.

Mudah Memahami dan Menganalisis Indikator Ekonomi. Yogyakarta: UPP STIM YKPN, 2013.

Lukman. Modul I Praktikum Statistk Laboratorium Alat Analisis Kuantitatif. Jakarta: UIN Syarif Hidayatullah. 2008.

Marthon, Said Sa'ad. Ekonomi Islam di Tengah Krisis Global. Jakarta: Zikrul Hakim, 2004.

Noegraha, Ridjaluddin Fadjar. Nuansa-Nuansa Ekonomi Islam. Jakarta: Sejahtera. 2007.

Perwataatmadja, Karnaen A. dan Hendri Tanjung. Bank Syariah: Teori, Praktik, dan Peranannya. Jakarta: Celestial Publishing, 2007.

Prides, Tim Manajemen. Kompilasi Perundang-Undangan tentang Ekonomi Syariah. Jakarta: Gaung Persada Press, 2008.

Rahardja, Prathama dan Mandala Manurung. Teori Ekonomi Makro Suatu Pengantar. Jakarta: Lembaga Penerbit FE UI, 2008.

Redaksi Laporan Utama. "Dicari Bankir Syariah yang Komunikatif". Sharing: Majalah Ekonomi dan Syariah, edisi 19, Juli 2008.

Rivai, Veithzal dan Antoni Nizar Usman. Islamic Economics and Finance: Ekonomi dan Keuangan Islam Bukan Alternatif, Tetapi Solusi. Jakarta: Gramedia Pustaka Utama, 2012.

Rivai, Veithzal dan Rifki Ismail. Islamic Risk Management for Islamic Banking: Risiko Bukan untuk Ditakuti, Tapi Dihadapi dengan Cerdik, Cerdas, dan Professional. Jakarta: Gramedia Pustaka Utama, 2013.

Rochaety, Ety dkk. Metodologi Penelitian Bisnis dengan Aplikasi SPSS. Jakarta: Mitra Wacana Media, 2009.

Saeed, Abdullah. Menyoal Bank Syariah: Kritik atas Interpretasi Bunga Bank Kaum Neo-Revivalis. Terj Arif Maftuhin. Jakarta: Paramadina, 2006.

Sari, Aisha Putrina dkk. "Strategi Pembiayaan Perbankan Syariah dalam Mendukung Keuangan Inklusif Bagi Sektor Mikro Melalui Pendekatan ANP (Analytic Network Process)". Makalah The 2nd Islamic Economics and Finance Research Forum (2013):13.

Al-Shadr, Muhammad Baqr. Keunggulan Ekonomi Islam: Mengkaji Sistem Ekonomi Barat dengan Kerangka Pemikiran Sistem Ekonomi Islam, Terj. Muhammad Hashem. Jakarta: Pustaka Zahra, 2002. 
. Buku Induk Ekonomi Islam: Iqtishaduna. Terj. Yudi. Jakarta: Zahra Publishing, 2008.

Siswanto. "Pengembangan Kualitas SDM Perbankan Syariah Integratif Melalui Implementasi Workplace Spirituality." Makalah The 2nd Islamic Economics and Finance Research Forum (2013): 13 - 14.

Suliswanto, Muhammad Sri Wahyudi. "Pengaruh Produk Domestik Bruto (PDB) dan Indeks Pembangunan Manusia (IPM) terhadap Angka Kemiskinan di Indonesia." Jurnal Ekonomi Pembangunan 8 No. 2 Desember (2010): 357-366.

Swasono, Sri Edi. Kembali ke Pasal 33 UUD 1945 Menolak Neoliberalisme. Jakarta: Yayasan Hatta, 2010.

Suyanto, Bagong. "Kemiskinan dan Pemberdayaan Masyarakat Miskin." Jurnal Masyarakat, Kebudayaan, dan Politik XIV No. 4 (2001): 38.

Al-Tamimi, Khaled Abdalla Mohd Al-Tamimi. "The Role of Islamic Banks Operating in Jordan in Economic Development." Journal of Economics and Sustainable Development 4 No. 8 (2013): 46-59.

Tanjung, Hendri dan Abrista Devi. Metodologi Penelitian Ekonomi Islam. Jakarta: Gramata Publishing, 2013.

Winarno, Wing Wahyu. Analisis Ekonometrika dan Statistika dengan Eviews. Yogyakarta: Unit Penerbit STIM YKPN. 2011.

Z, A. Wangsawidjaja. Pembiayaan Bank Syariah. Jakarta: Gramedia Pustaka Utama, 2012.

Safaah Restuning Hayati, Forum Studi Ekonomi "Equlibrium", restuning2112@gmail.com 